\title{
Sistem Informasi Penelitian dan Pengabdian Masyarakat di Universitas Mohammad Husni Thamrin
}

\author{
Rano Agustino*1, Yohanes Bowo Widodo ${ }^{2}$, Mohammad Ikhsan Saputro ${ }^{3}$, \\ Agus Wiyatno ${ }^{4}$ \\ ${ }^{1,3}$ Sistem Informasi, Fakultas Komputer Universitas Mohammad Husni Thamrin, Jakarta. \\ ${ }^{2}$ Teknik Informatika, Fakultas Komputer Universitas Mohammad Husni Thamrin. \\ ${ }^{4}$ Sistem Informasi, Fakultas Komputer STMIK Nusa Mandiri, Jakarta. \\ e-mail: ${ }^{1}$ rano.agustino@gmail.com, ${ }^{2}$ ybowowidodo@gmail.com, \\ ${ }^{3}$ m.ikhsan68@gmail.com, ${ }^{4}$ gus.cvn@gmail.com,
}

\begin{abstract}
The Institute for Research and Community Service or Lembaga Penelitian dan Pengabdian Masyarakat $(L P P M)$ is an activity institution at the University Mohammad Husni Thamrin (UMHT) which functions to manage all research and community service activities. Every research conducted by lecturers aims to improve their quality in gathering tri dharma values, especially on research and community service. But at this time the processing of research data and community service to the LPPM UMHT has not used a database because the data processing uses excel and data archiving is still in physical form which can make it difficult to find data when the data is needed. Data management by using a database and a special application program is expected to be able to support an information system that is fast and accurate, so that the problem of time and the level of effectiveness in managing research data and community service can be optimized. In addition, the need for information from this institution is needed in a fast and appropriate condition to support the improvement of the quality of lecturers and others in terms of research and community service.
\end{abstract}

Keywords-Information Systems LPPM, Database System LPPM, Design Application LPPM

\section{PENDAHULUAN}

1.1. Latar Belakang

Pengelola Perguruan Tinggi (PT) diharapkan dapat memfasilitasi kegiatan penelitian dan pengabdian di lingkungan perguruan tinggi yang mereka ajar. Karena penelitian dan pengabdian kepada masyarakat sudah menjadi bagian yang penting dalam Tri Dharma PT. Penelitian dan pengabdian adalah salah satu yang harus ditunaikan oleh dosen untuk melengkapi syarat Tri Dharna. Oleh sebab itu PT harus dapat terlibat aktif dalam kegiatan penelitian dan pengabdian. Hal tersebut diharapkan bisa menjadikan dosen lebih terpacu dalam meningkatkan kualitas diri dalam melakukan penelitian dan pengabdian

Universitas MH Thamrin memilik sebuah lembaga organisasi yang bernama LPPM (Lembaga Penelitian dan Pengabdian pada Masyarakat) yang memiliki fungsi untuk mengelola semua kegiatan penelitian dan pengabdian kepada masyarakat. Kegiatan penelitian itu dilakukan oleh dosen untuk meningkatkan kualitas pada dosen. Namun pada saat ini pengolahan data-data penelitian maupun pengabdian pada LPPM belum tersistem atau terkomputerisasi dengan baik karena pekerjaan nya masih menggunakan pengarsipan berupa fisik yang mana hal ini dapat mempersulit dalam pencarian data ketika data tersebut diperlukan.

Pengelolaan dengan komputerisasi 
menggunakan program aplikasi khusus pengelolaan data pengabdian dan penelitian diharapkan dapat mendukung sebuah sistem informasi yang cepat dan akurat, sehingga permasalahan waktu dan tingkat efektifitas dalam mengelola data penelitian dan pengabdian masyarakat dapat dioptimalisasikan. Selain itu kebutuhan terhadap informasi dari lembaga ini sangat diperlukan dalam kondisi yang cepat dan tingkat akurasi informasi yang tinggi untuk mendukung perkembangan dosen dan Perguruan Tinggi serta yang lain nya yang terlibat pada penelitan dan pengabdian kepada masyarakat

\subsection{Perumusan Masalah}

Rumusan masalah pada penelitian ini adalah bagaimana merancang sistem informasi untuk mendukung kegiatan pengabdian dan penelitian pada LPPM di Universitas MH Thamrin

\subsection{Tujuan Dan Manfaat Penelitian}

1.3.1. Tujuan Penelitian

Tujuan dari penelitian ini adalah menghasilkan dokumentasi dari rancangan sistem informasi dan program aplikasi untuk mendukung kegiatan penelitian dan pengabdian kepada masyarakat dalam hal pengelolaan data di Universitas MH Thamrin.

\subsubsection{Manfaat Penelitian}

a. Membuat dokumentasi perancangan sistem informasi penelitian dan pengabdian di LPPM Universitas MH Thamrin.

b. Membuat program aplikasi penelitian dan pengabdian di LPPM Universitas MH Thamrin

\subsection{Kajian Penelitian Sebelum nya}

Aplikasi Penelitian Dosen Berbasis

Web. Dede Supriyadi (2018) Dalam penelitian ini peneliti membuat aplikasi ini ditujukan untuk seluruh dosen STMIK Eresha, yang mana nantinya dosen dapat mengunggah hasil penelitian mereka langsung lewat website ini. Bahasa pemograman yang digunakan menggunakan PHP [1].

Rancang Bangun Sistem Informasi Penelitian Dan Pengabdian Dosen Fakultas Teknologi Informasi Dan Komunikasi (FTIK) Universitas Semarang (USM). Sri Handayani (2017). Sistem informasi penelitian dan pengabdian kepada masyarakat FTIK USM berfungsi untuk membantu admin UP2M FTIK USM dalam mengelola data penelitian dan pengabdian kepada masyarakat, serta memonitoring pelaksanaan penelitian dan pengabdian [2].

Aplikasi E-Data penelitian dosen menggunakan web (Pratiwi, 2012) Aplikasi E-data meringankan dosen dalam pengiriman data penelitian yang telah dilakukan dari berbagai sumber dengan jangkauan yang sangat luas tanpa harus bertatap muka secara langsung dengan pihak terkait sehingga dapat menghemat biaya dan waktu. Aplikasi ini telah dilakukan oleh dosen Jurusan Akuntasi Fakultas Ekonomi, Universitas Gunadarma.[3].

\subsection{Landasan Teori}

\subsubsection{Perancangan Sistem}

Menurut George M.Scott ( Jogiyanto, HM : 1991) Suatu jaringan kerja yang saling berhubungan untuk menunjukan bagaimana suatu sistem menyelesaikan apa yang mesti diselesaikan disebut perancangan. [4]

Analisa sistem adalah panguraian dari suatu sistem informasi yang utuh ke dalam bagian-bagian komponennya dengan tujuan untuk mengidentifikasi dan mengevaluasi berbagai macam permasalahan, kesempatan, hambatan yang terjadi dan kebutuhan yang diharapkan sehingga muncul perbaikan perbaikan yang dapat diusulkan (Jogianto, 2005) [5].

Perancangan adalah proses penerapan berbagai macam teknik serta prinsip dengan maksud untuk mentransformasikan hasil analisa ke dalam bentuk yang memudahkan mengimplementasikan. Dari pengertian 
tersebut maka dapat disimpulkan bahwa perancangan adalah suatu kegiatan yang berhubungan dengan evaluasi yang telah dilakukan pada kegiatan analisis (Kadir, 2003) [5].

\subsubsection{UML (Unified Modelling Language)}

UML (Unified Modeling Language) adalah 'bahasa' pemodelan yang digunakan sistem atau software yang memiliki paradigma "berorientasi objek". Pemodelan (modeling) digunakan untuk menyederhanakan permasalahan kompleks sehingga lebih mudah dipelajari dan dipahami (Nugroho, 2016). [6]

Sedangkan menurut (Mujilan, 2013) UML (Unified Modeling Language) adalah sebuah standar bahasa industri untuk menggambarkan, merancang dan mendokumentasikan sistem piranti lunak dalam industri untuk. [7]

\subsection{2. Хатpp}

Menurut Wahana dalam (Agus \& Safitri, 2015) "XAMPP adalah salah satu paket instalasi apache, PHP, dan MySQL secara instant yang dapat digunakan untuk membantu proses instalasi ketiga produk tersebut"'[8].

\subsubsection{PHP}

Menurut Anhar dalam (Suryanto, 2016) "PHP yang adalah singkatan dari Page hypertext Preprocessor yaitu script yang terintegrasi dengan HTML dan berada pada server (server side HTML embedded scripting)" [9].

Sedangkan menurut (Raharjo, 2018) PHP merupakan bahasa yang mendukung pemrograman yang memiliki orientasi pada objek. Data yang dibutuhkan oleh program dapat diperankan sebagai objek (wujud nyata atau Instance dari suatu kelas tertentu) [10].

\subsubsection{Database}

Menurut (Puspitasari, 2017) "MySQL merupakan basis data yang dikembangkan dari bahasa Structure Query Language atau yang biasa dikenal dengan SQL. MySQL dapat dinyatakan sebagai Relational Database Management
System (RDBMS), yaitu hubungan antar tabel yang berisi data pada suatu database. Dengan demikian dapat mempercepat pencarian suatu data SQL merupakan bahasa terstruktur yang digunakan untuk interaksi antara script program dengan database server dalam hal pengolahan data" [11].

Adapun definisi menurut Nugroho dalam (Permana, 2018) basis database yang berbasiskan server adalah MySQ. Database MySQL dapat digunakan apabila pengguna memiliki hak akses di dalam nya. Hal tersebut sama dengan Ketika pengguna hendak menggunakan klien MySQL untuk masuk pada server MySQL. Pengguna yang menggunakan program PHP, dapat mengakses database MySQL terlebih dahulu menggunakan koneksi [12].

\section{METODE PENELITIAN}

Penelitian ini merupakan jenis penelitian Research and Development (R\&D). Penelitian dan pengembangan adalah metode penelitian yang digunakan untuk menghasilkan produk tertentu, dan menguji keefektifan produk tersebut. (Sugiyono, 2017). Pendapat lain mendefinisikan penelitian dan pengembangan merupakan pendekatan penelitian untuk menghasilkan produk baru atau menyempurnakan produk yang telah ada. (Sukmadinata, 2006).

\subsection{Metode Pengambilan Data}

. Pengertian Adapun teknik-teknik pengumpulan data yang peneliti lakukan dalam penelitian adalah sebagai berikut:

1. Metode Pengamatan (Observasi ) Melalui metode ini penulis melakukan pengamatan langsung pada bagian LPPM di Universitas $\mathrm{MH}$ Thamrin dengan melihat objek secara teliti dalam waktu yang bersamaan. Metode ini bersifat umum tapi menyeluruh dan manfaat nya dapat dipakai sebagai dasar untuk penelitian yang lebih baik dikedepan nya nanti.

2. Metode Wawancara 
Submitted:27 Oktober 2019 Revised: 10 Januari 2020; Accepted: 18 Maret 2020; Published: 1 April 2020

Wawancara yang dilakukan ini bertujuan untuk mendapatkan informasi secara lengkap dan untuk mendapatkan hal tersebut penulis melakukan tanya jawab dengan bagian administrasi dan ketua LPPM Universitas MH Thamrin.

\section{Studi Pustaka}

Selain melakukan dua metode penelitian di atas, penulis juga melakukan pengumpulan data dengan menggunakan studi pustaka. Pada teknik pengumpulan data dengan studi pustaka, penulis berusaha melengkapi data-data yang diperoleh dengan membaca dan mempelajari jurnal, buku-buku, dan data yang relevan yang berkaitan dengan masalah sistem informasi terkait penelitian dan pengabdian.

\subsection{Metode Pengembangan Software}

Dalam pembuatan program ini penulis menggunakan metode pengembangan software SDLC (System Development Life Cycle) dengan model waterfall. (Sukamto, 2013) menerangkan bahwa "Software Development Life Cycle atau System Development Life Cycle merupakan salah satu proses mengembangkan atau mengubah suatu sistem perangkat lunak dengan penggunaan model-model dan metodologi sebelumnya, berdasarkan best practice atau cara-cara yang sudah teruji baik [13].

Selanjut nya (Sukamto, 2013) menjelaskan bahwa model waterfall sering juga disebut model sekuensi linear atau alur hidup klasik. Berikut ini adalah gambar dari model waterfall. Model waterfall dapat dilihat pada Gambar 1 [13].

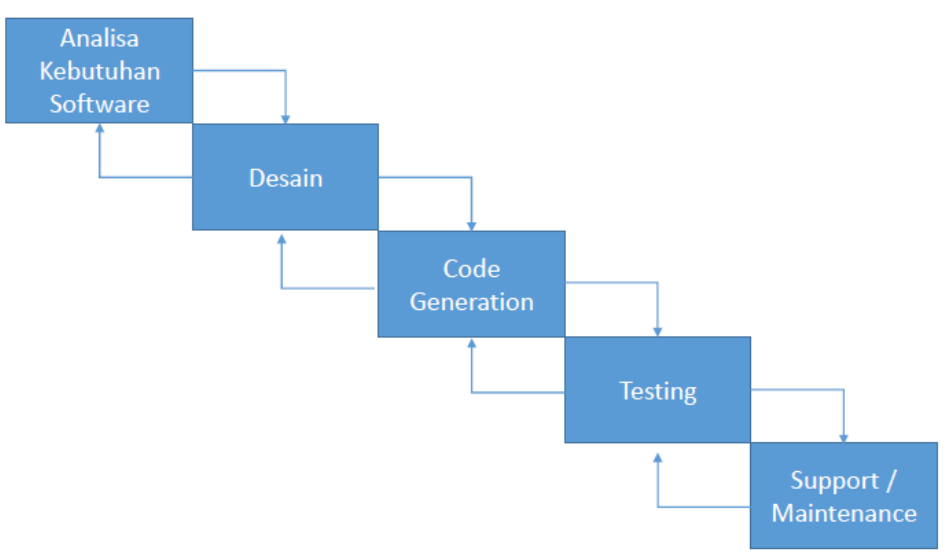

Gambar 1. Model Waterfall

Berikut ini adalah penjelasan dari tahapan SDLC model waterfall:

1. Analisis kebutuhan software Pada proses ini, dilakukan analisa dan pengumpulan kebutuhan sistem informasi LPPM di Universitas MH Thamrin yang meliputi dokumen, data dan interface yang dibutuhkan untuk mengetahui kebutuhan dan menentukan software dan tools yang akan digunakan.

2. Desain

Desain pada proses ini berfokus pada perancangan struktur data, arsitektur perangkat lunak, representasi interface atau tampilan dan desain system dengan menggunakan UML.

3. Code Generation

Pengkodean (Code Generation) merupakan salah satu proses dalam menterjemahkan perancangan desain yang dapat dipahami oleh mesin, melalui bahasa pemprograman.

4. Testing Pengujian (Testing)

Pada program perangkat lunak, baik pengujian blackbox dan pengujian 
whitebox untuk memeriksa segala kemungkinan terjadi kesalahan dan memeriksa apakah hasil dari pengembangan tersebut sudah mencapai hasil yang diinginkan.

5. Support

Proses ini merupakan bagian paling akhir dari proses pengembangan dan dilakukan setelah perangkat lunak digunakan. Kegiatan yang dilakukan yaitu dengan memelihara sistem informasi penelitian dan pengabdian masyarakat pada universitas $\mathrm{MH}$ Thamrin.

\subsection{Analisa Sistem}

Proses analisis sistem yang dilakukan pada penelitian ini yaitu analisis terhadap kebutuhan fungsional dan kebutuhan non fungsional pada Lembaga Penelitian dan Pengabdian Masyarakat (LPPM) di Universitas Mohammad Husni Thamrin. Untuk menggambarkan kebutuhan tersebut, metode/teknik yang digunakan pada penelitian ini adalah teknik/metode UML (Unified Modelling Language) diagram di antara nya menggunakan usecase diagram, activity diagram dan sequential diagram.

\subsubsection{Usecase Diagram}

Gambar 2 merupakan gambar usecase diagram pada sistem LPPM. Actor pada sistem ini adalah admin. Admin dapat melakukan beberapa kegiatan atau proses usecase yaitu; Olah Data Dosen, Olah Data Penelitian, Olah Data Pengabdian, Olah Data Publikasi yang terdiri dari Olah Data Haki, Olah Data Artikel Ilmiah, Olah Data Buku Ajar dan Olah Data Jurnal

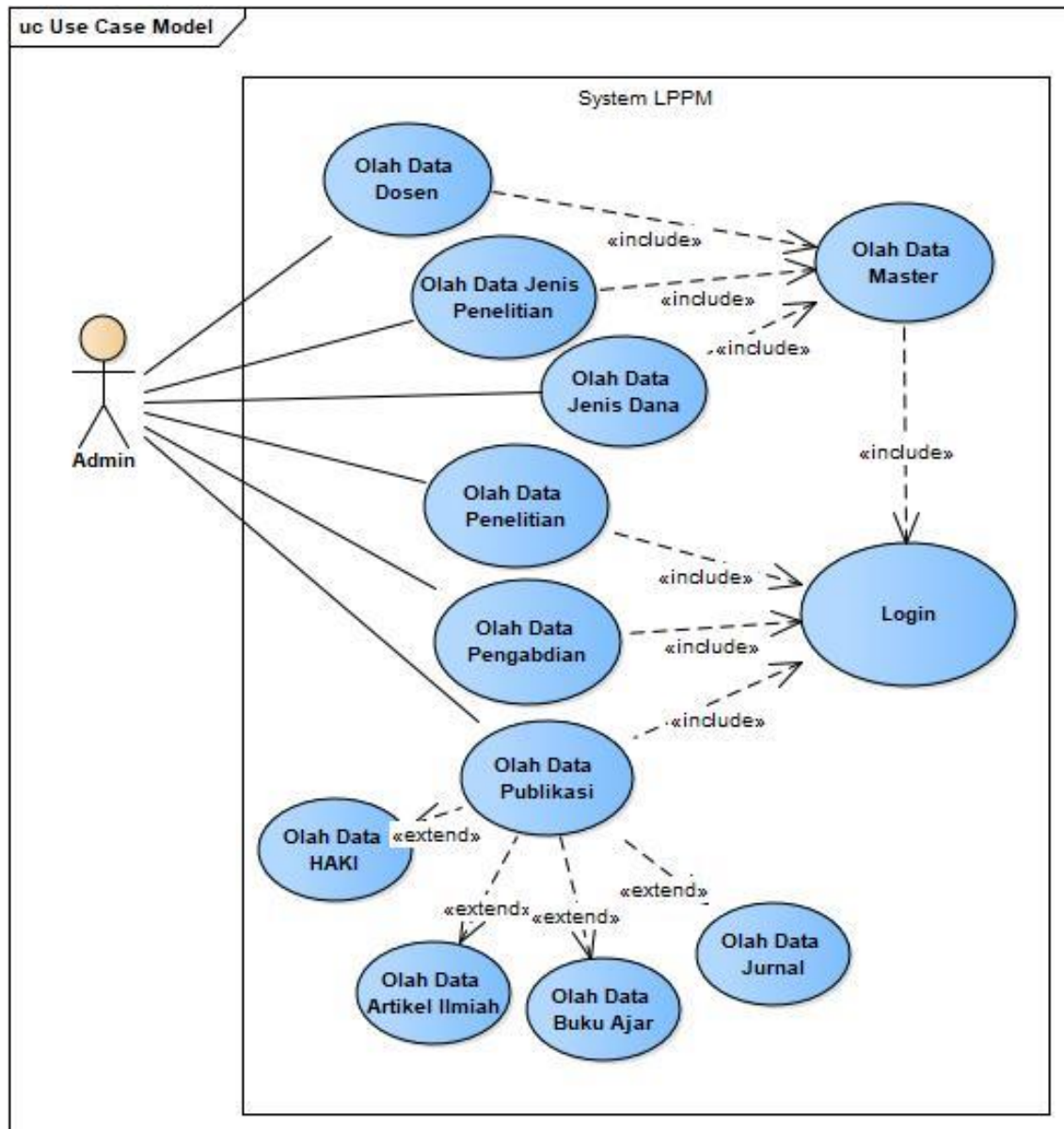

Gambar 2. Usecase Diagram

\subsubsection{Activity Diagram}


Rano Agustino, Yohanes Bowo Widodo, Mohammad Ikhsan Saputro, Agus Wiyatno

Submitted:27 Oktober 2019 Revised: 10 Januari 2020; Accepted: 18 Maret 2020; Published: 1 April 2020

Gambar 3, 4, 5, 6, 7, 8, dan 9 merupakan gambar dari activity diagram LPPM di Universitas MH Thamrin.

Gambar 3 merupakan gambar Olah Data Dosen, Gambar 4 merupakan gambar Olah Data Penelitian, Gambar 5 merupakan gambar Olah Data Pengabdian, Gambar 6 merupakan gambar Olah Data Jurnal, Gambar 7 merupakan gambar Olah Data HAKI, Gambar 8 merupakan gambar Olah Data Artikel, dan Gambar 9 merupakan gambar Olah Data Buku.

1. Activity Diagram Olah Data Dosen

Gambar 3 merupakan gambar activity diagram untuk Olah Data Dosen.

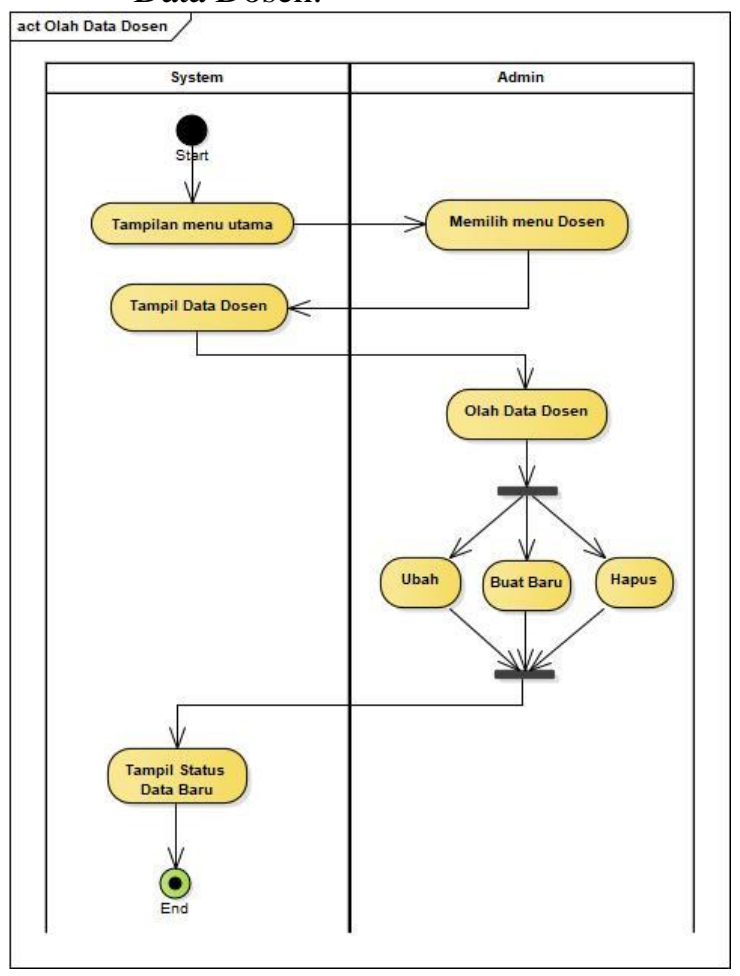

Gambar 3. Activity Diagram Olah

Data Dosen
Activity Diagram Olah Data Penelitian

Gambar 4 merupakan gambar activity diagram untuk Olah Data Penelitian.

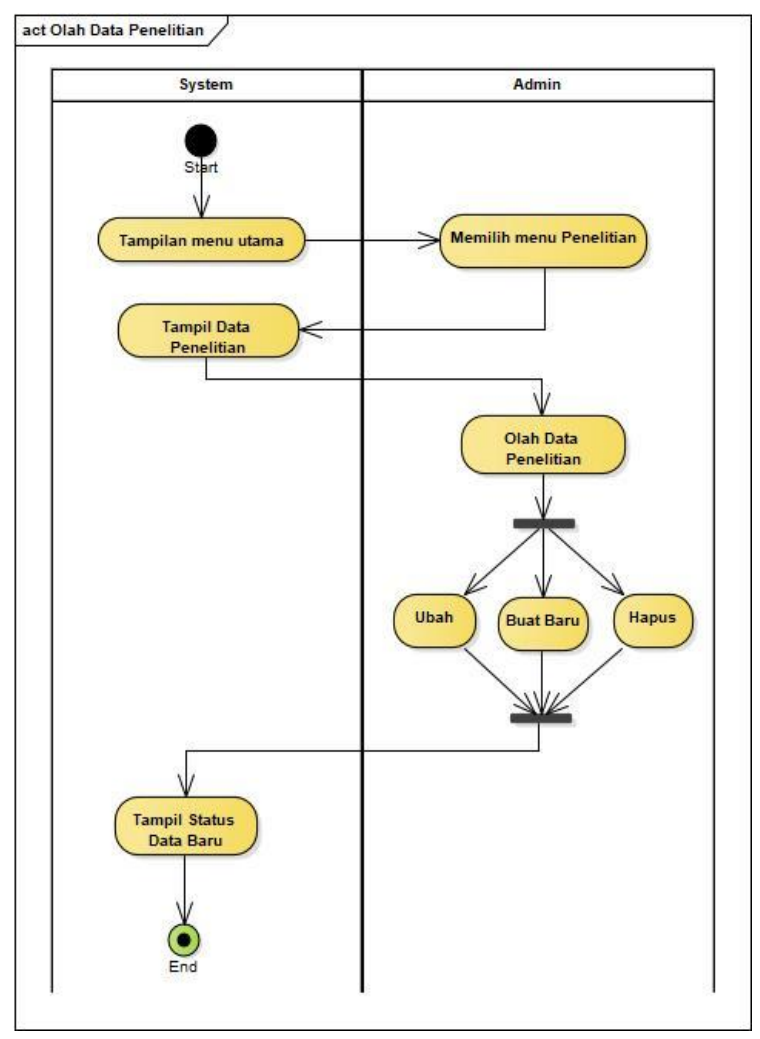

Gambar 4. Activity

Diagram Olah Data

Penelitian

2. Activity Diagram Olah Data Pengabdian

Gambar 5 merupakan gambar activity diagram untuk Olah Data Pengabdian. 


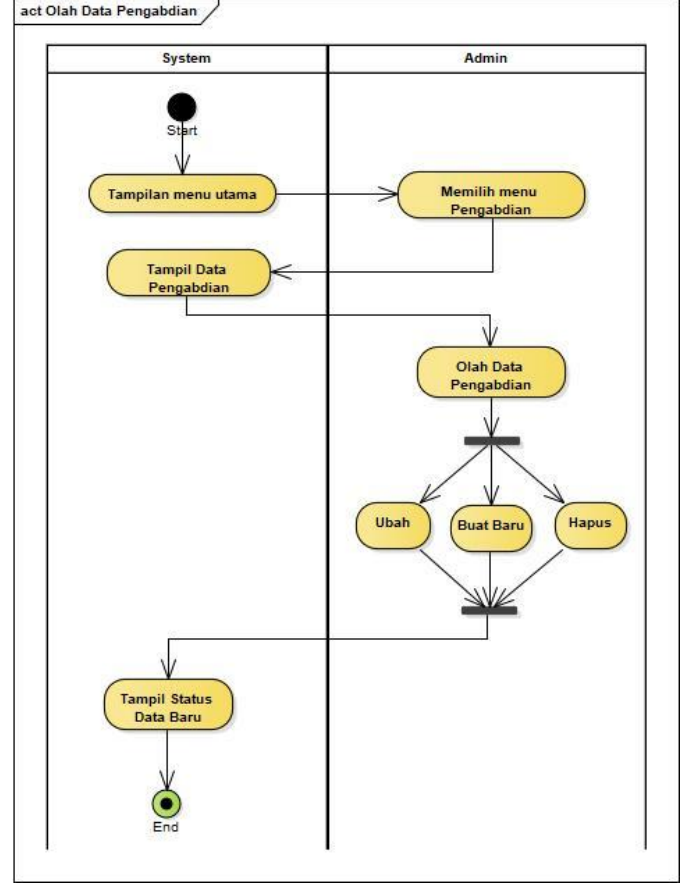

Gambar 5. Activity Diagram

Olah Data Pengabdian

3. Activity Diagram Olah Data Jurnal

Gambar 6 merupakan gambar activity diagram untuk Olah Data Jurnal

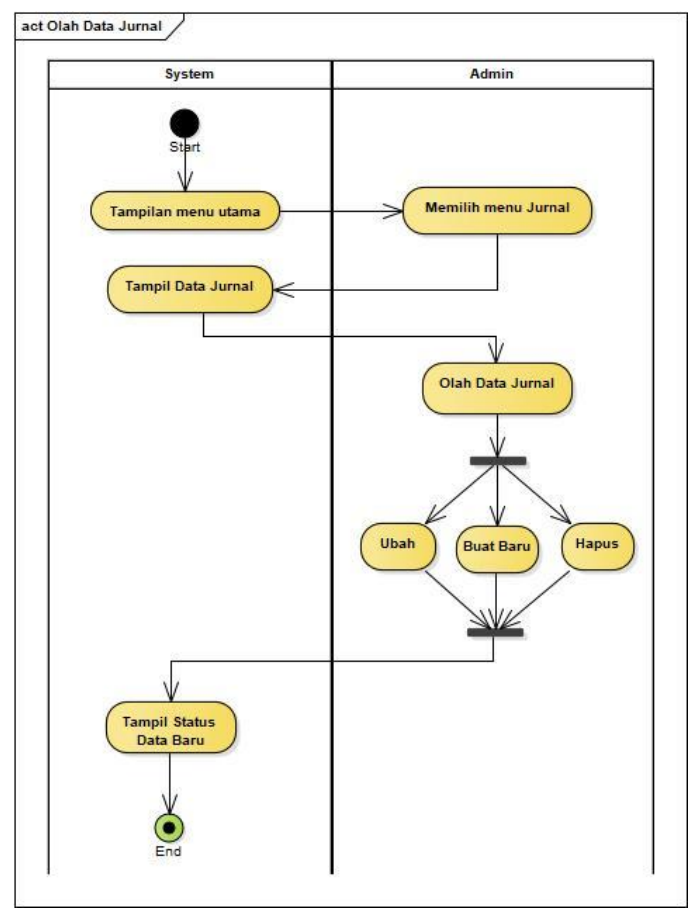

Gambar 6. Activity Diagram Olah Data Jurnal
4. Activity Diagram Olah Data HAKI

Gambar 7 merupakan gambar activity diagram untuk Olah Data HAKI

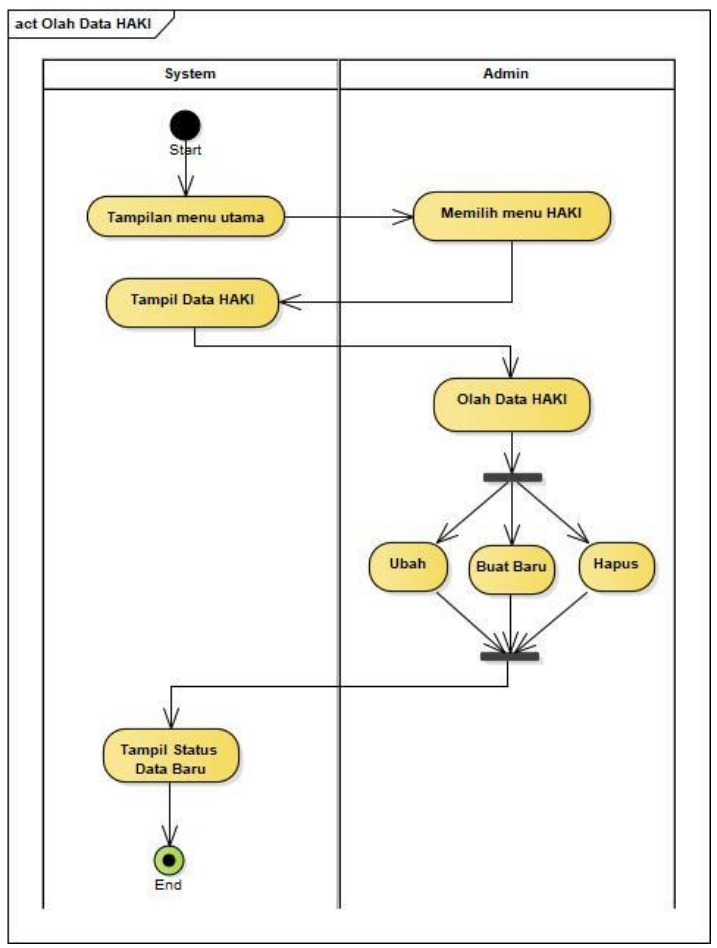

Gambar 7. Activity Diagram

Olah Data HAKI

5. Activity Diagram Olah Data

Artikel Ilmiah

Gambar 8 merupakan gambar activity diagram untuk Olah Data Artikel Ilmiah

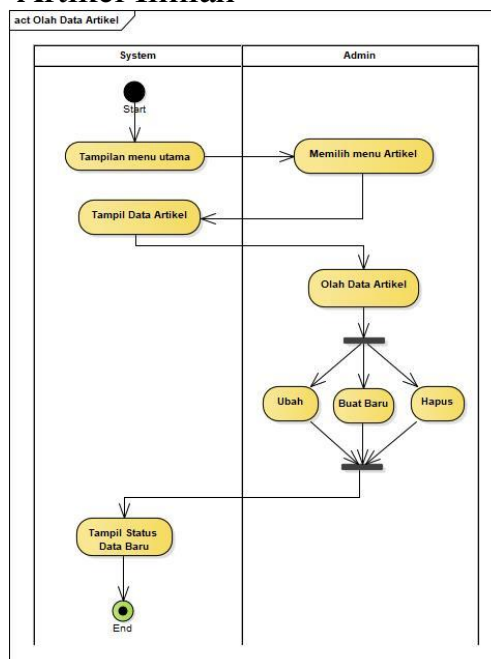

Gambar 8. Activity Diagram Olah Data

Artikel 
Rano Agustino, Yohanes Bowo Widodo, Mohammad Ikhsan Saputro, Agus Wiyatno

Submitted:27 Oktober 2019 Revised: 10 Januari 2020; Accepted: 18 Maret 2020; Published: 1 April 2020

6. Activity Diagram Olah Data Buku

Gambar 9 merupakan gambar activity diagram untuk Olah Data Buku

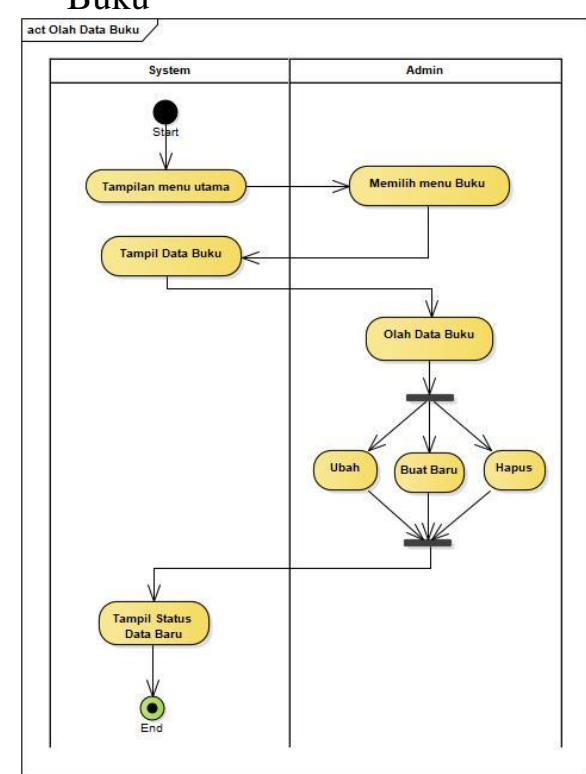

Gambar 9. Activity Diagram Olah Data Buku

\subsection{Entity Relational Diagram.}

Gambar 10 merupakan gambar ERD (Entity Relation Diagram) pada sistem penelitian dan pengabdian di UMHT

\subsection{Struktur Navigasi}

Struktur navigasi yang digunakan untuk aplikasi ini adalah struktur navigasi campuran. Berikut ini adalah gambar dari struktur navigasi menu pada sistem penelitian dan pengabdian di
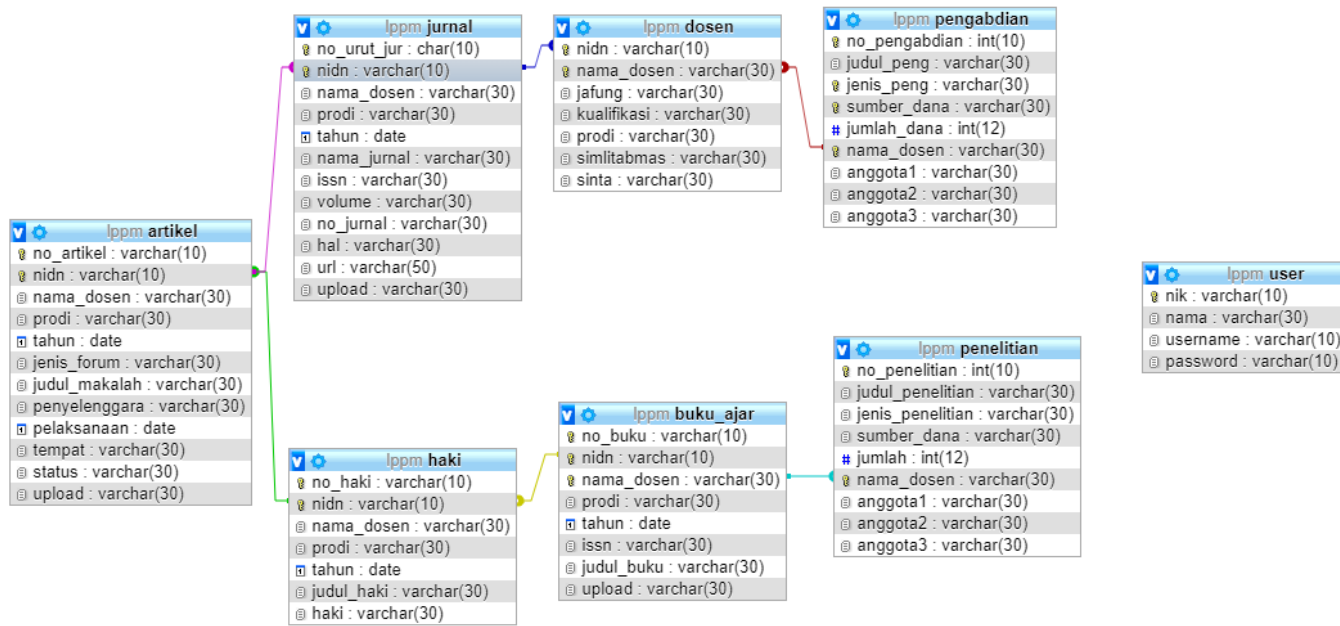

enama : $\operatorname{varchar}(30)$ password : varchar $(10)$
1. Data Master

Data master memiliki sub menu diantara nya menu dosen, Jenis Pengabdian, Jenis Penelitian dan Jenis Dana.

2. Data Transaksi

Data Transaksi memilik sub menu diantara nya menu Penelitian , Publikasi dan Pengabdian. Menu Publikasi memelik empat sub menu, diantara nya Jurnal, HAKI, Artikel dan Buku.

3. Cetak Laporan

Cetak Laporan memiliki enam sub menu diatanra nya adalah sub menu Cetak Data Penelitian, Cetak Data Pengabdian, Cetak Data Jurnal, Cetak Data HAKI, Cetak Data Artikel dan Cetak Data Buku.

Gambar 10. ERD sistem LPPM UMHT 


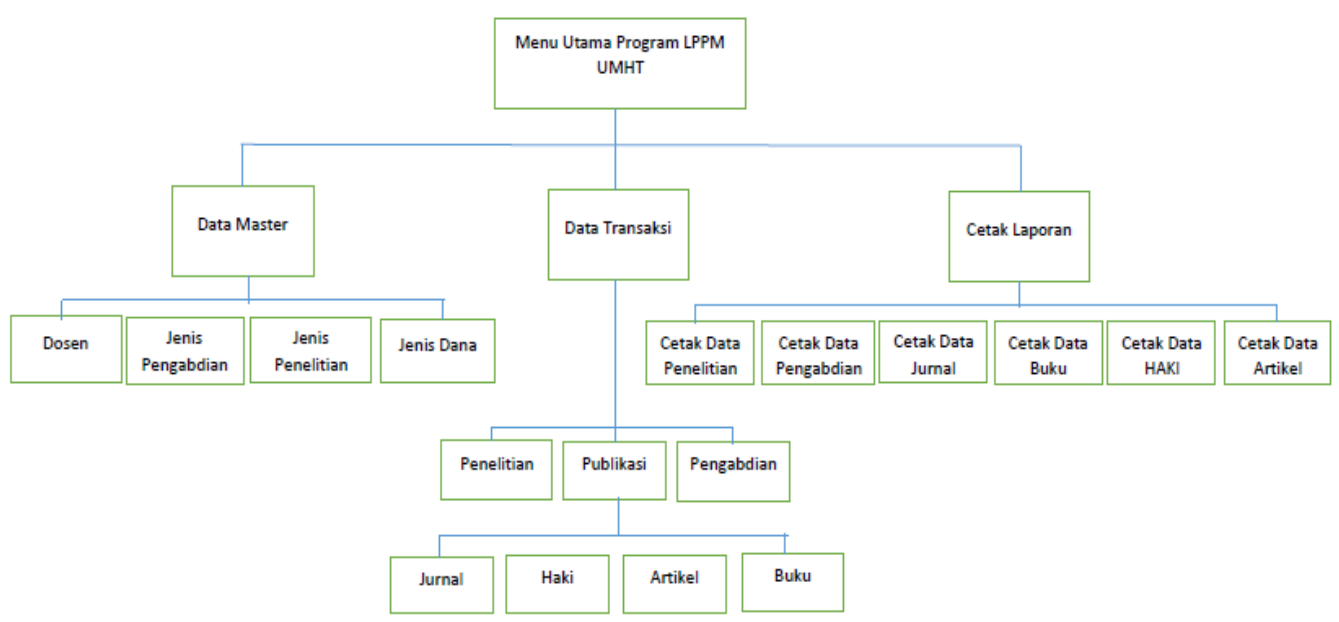

Gambar 11. Struktur Navigasi Sistem Penelitian

\section{HASIL DAN PEMBAHASAN}

Hasil dari penelitian ini adalah sebuah dokumentasi atau blueprint dari hasil analisa sistem yang disesuaikan dengan user. Dalam hal ini user adalah pihak dari LPPM di UMHT. Selain dokumentasi, hasil dari penelitian ini juga membuat sebuah aplikasi yang sesuai dengan analisa sistem yaitu aplikasi Sistem Informasi Penelitian dan Pengabdian yang di sesuaikan dengan permintaan dari LPPM UMHT pada saat kami melakukan FGD (Focus Group Discussion). Gambar 12 adalah gambar tampilan pengguna aplikasi penelitian dan pengabdian LPPM di UMHT.

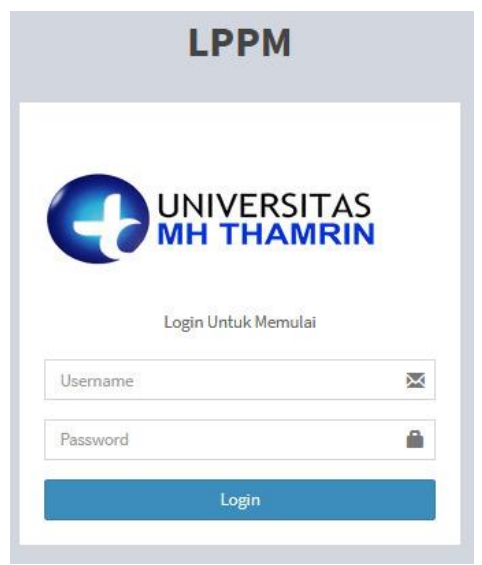

Gambar 12. Tampilan Login Aplikasi LPPM UMHT

A. Tampilan Login.

B. Tampilan Utama Aplikasi LPPM UMHT

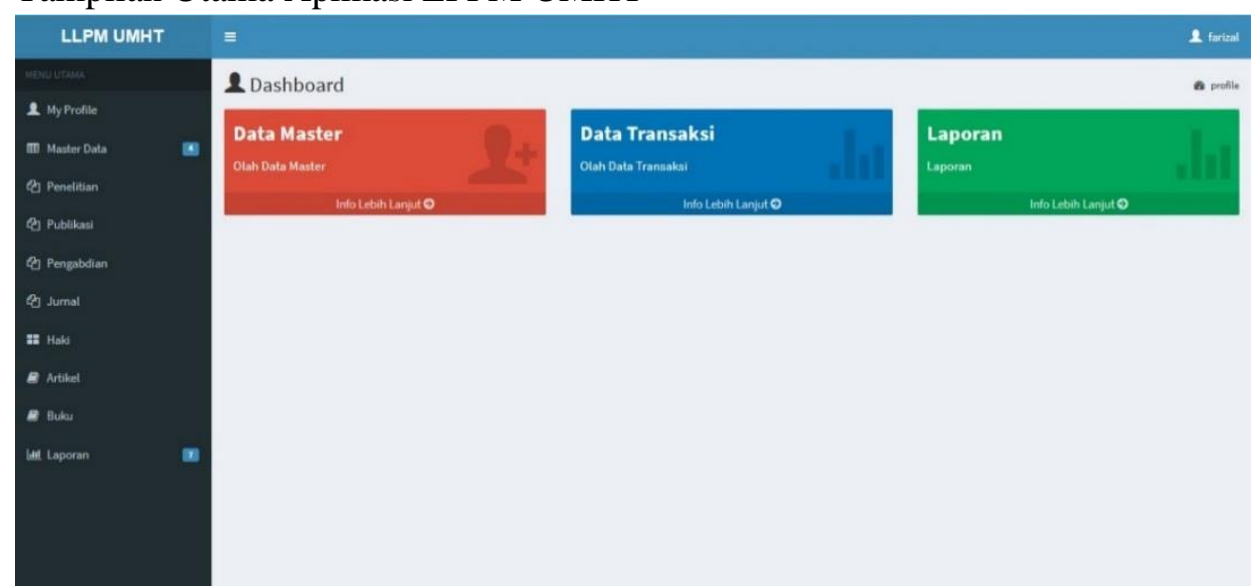

Gambar 13. Tampilan Menu Utama 
Rano Agustino, Yohanes Bowo Widodo, Mohammad Ikhsan Saputro, Agus Wiyatno Submitted:27 Oktober 2019 Revised: 10 Januari 2020; Accepted: 18 Maret 2020; Published: 1 April 2020

C. Tampilan Form Data Master Dosen

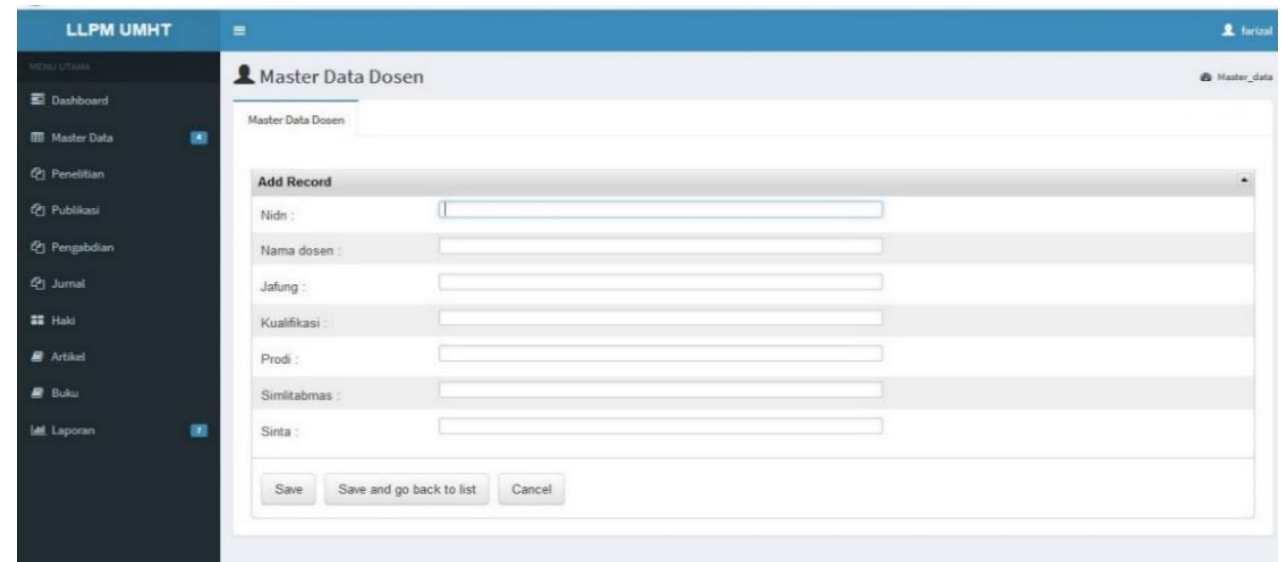

Gambar 14. Tampilan Data Master

D. Tampilan Form Pencarian Data Dosen

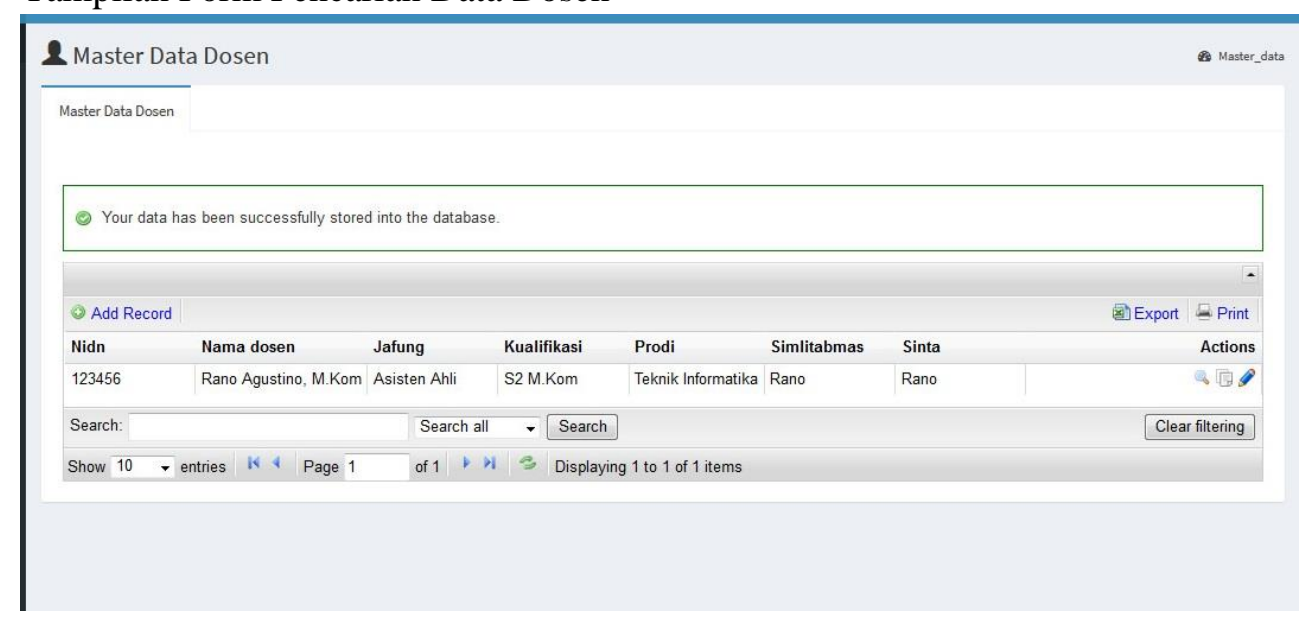

E. Tampilan Form Jurnal

Gambar 15. Tampilan Data Master

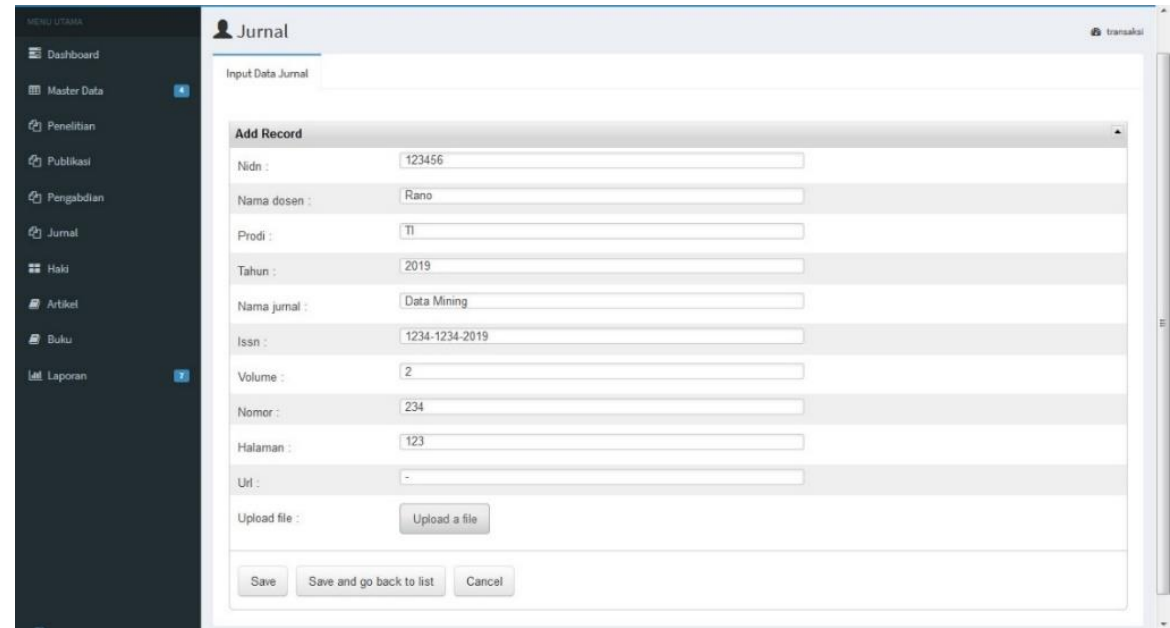

Gambar 16. Tampilan Form Jurnal

KESIMPULAN DAN SARAN 
Berdasarkan hasil dari penelitian yang telah penulis laksanakan maka kami mengambil beberapa kesimpulan, diantara nya ;

1. Sistem informasi penelitian dan pengabdian kepada masyarakat pada Universitas MH Thamrin dibuat untuk membantu tugas dari admin LPPM (Lembaga Pengabdian Kepada Masyarakat dalam mengelola data dan memonitoring pelaksanaan penelitian dan pengabdian bagi dosen UMHT.

$$
\text { 2. Dengan adanya }
$$

dokumentasi perancangan sistem informasi penelitian dan pengabdian di LPPM Universitas MH Thamrin ini diharapkan dapat digunakan dalam pengembangan aplikasi LPPM UMHT nanti nya, dan dapat mempermudah dalam memperbaiki kesalahan atau error bila nanti terjadi. Adapun saran pada penelitian ini, yaitu:

1. Diharapkan untuk penelitian berikut nya dapat mengembangkan aplikasi ini menjadi aplikasi android, aplikasi andoid ini bertujuan untuk para dosen UMHT untuk dapat melihat data mereka masing masing langsung dari gadget mereka, dengan tujuan agar tidak tergantung kepada admin LPPM pada saat melihat data masing masing dosen.

2. Diharapkan untuk penelitian berikut nya data data hasil olahan LPPM pada UMHT ini dapat diolah dengan cara mining data dengan menggunakan beberapa algoritma pada data mining. Hasil dari olahan tersebut akan bermanfaat bagi manajemen dalam menunjang keputusan dalam hal penelitian dan pengabdian.

\section{UCAPAN TERIMA KASIH}

Alhamdulillah puji syukur kehadiran Allah S.W.T yang telah memberikan kami kesempatan untuk menyelesaikan penelitian ini. Dan juga kami berterima kasih kepada LPPM UMHT yang telah memberikan dukungan moril dan materil kepada peneliti untuk menyelesaikan penelitian ini

\section{DAFTAR PUSTAKA}

[1] Supriyadi, Dedi 2018, Aplikasi Penelitian Dosen Berbasis Web. Jurnal Teknologi Informasi ESIT Vol. XII No. 01 April 2018

[2] Handayani ,Sri, 2017. Rancang Bangun Sistem Informasi Penelitian Dan Pengabdian Dosen Fakultas Teknologi Informasi Dan Komunikasi (FTIK) Universitas Semarang (USM). INFOKAM Nomor I Th. XIII/MARET/2017 [2]009

[3] Pratiwi, C.W. and Astuti, I., 2012. Aplikasi E-Data Penelitian Dosen Berbasis WEB. Konferensi Nasional Sistem Informasi 2012, STMIK-STIKOM Bali 23-25 Pebruari 2012, (255)

[4] Jogiyanto, H.M., 2008. Metodologi penelitian sistem informasi. Yogyakarta: Andi Offset.

[5] Suwarno, A., 2017. Perancangan Sistem Informasi Pengadaan Bahan Baku Produksi Pada PT. Kohno Indonesia. Jurnal SIGMA, [S.1.], v. 6 , n. 1, p. Halaman $81-88$, mar. 2017.

[6] Nugroho, A. (2010). Rekayasa perangkat lunak berorientasi objek dengan metode USDP. Penerbit Andi..

[7] Mujilan, A., 2013. Analisis dan Perancangan Sistem. Universitas Widya Mandala. Madiun.

[8] Agus, P., 2015. Pemanfaatan Sistem Informasi Perpustakaan Digital Berbasis Website Untuk Para Penulis Agus Prayitno 1) Yulia Safitri 2. Indonesian Journal on Software Engineering, 1(1), pp.110.

[9] Anhar, S.T., 2010. Panduan Menguasai PHP \& MySQL Secara Otodidak. Jakarta: mediakita, 3

[10] Raharjo, B. 2018. Belajar Singkat PHP 7. Bandung : BI Obses 
Rano Agustino, Yohanes Bowo Widodo, Mohammad Ikhsan Saputro, Agus Wiyatno

Submitted:27 Oktober 2019 Revised: 10 Januari 2020; Accepted: 18 Maret 2020; Published: 1 April 2020

[11] Puspitasari, D., 2017. Sistem Informasi Persediaan Obat Berbasis Web Pada Klinik Dan Apotek Hermantoni Karawang. Jurnal Bianglala Informatika.

[12] Permana, R., 2018. Perancangan Program Persediaan Barang Dagang Pada Cv. Satria Jaya. Cki On Spot, 11(2).

[13] Rosa, A.S. and Shalahuddin, M., 2011. Modul Pembelajaran Rekayasa Perangkat Lunak (Terstruktur dan Berorientasi Objek). Bandung: Modula 